\title{
AHP Method to Support Decision Making for Sustainability
}

\author{
Wail El hilali ${ }^{1}$, Abdellah El manouar ${ }^{1}$, \& Mohammed Abdou Janati Idrissi ${ }^{1}$ \\ ${ }^{1}$ Mohammed V University in Rabat, Morocco \\ Correspondence: Wail El hilali, Mohammed V University in Rabat, Morocco.
}

Received: August 18, 2020

Accepted: October 27, 2020

Online Published: October 27, 2020

doi:10.5539/cis.v13n4p32

URL: https://doi.org/10.5539/cis.v13n4p32

\begin{abstract}
In these challenging times, finding a way to sustain the created value becomes a must. The fierce competition, the risk of disruption, the rise of customer awareness and the scarcity of resources, all these are few of many drivers that push companies to invest in sustainability. This paper is an attempt to enrich the literature about this subject. It mainly explores how to use the AHP method, a well-known multicriteria decision making technique, to decide about the right actions to implement, in order to reach sustainability. The paper is a continuity of a previous work that introduced a new framework that explained how companies could sustain their business models through information systems (IS). This approach was applied on a telecom operator, as a case study, to explain well how companies could choose the right actions to implement, in order to reach sustainability.
\end{abstract}

Keywords: Sustainability, AHP method, multicriteria decision making, information systems, business models.

\section{Introduction}

In this time and age, companies are facing huge challenges to sustain their ways of creating value. The real risk of disruption, the fierce competition among rivals, the change in the customer behaviors and the scarcity of resources, all these are few of many drivers that push companies to change their ways of doing business.

Finding a balance between their financial numbers, their social commitment and their negative externalities is the ultimate goal to achieve. Many studies are suggesting to work on business models, in order to sustain a given business as they fully describe how the value is created and captured. In many cases, managers and practitioners would be faced with different options: Should they change their customer experience? Should they reduce their costs or should they review their channels? ... These actions depend on the industry, the firm and its capabilities.

Decision making on sustainability involves complex interactions between ecological, economic and social aspects, as well as it requires active participation by all relevant stakeholders. Deciding on the right actions to adopt, requires the use of multicriteria decision making techniques that help to evaluate a set of alternatives in terms of a number of criteria. Among these techniques, the analytic hierarchy process, normally called AHP, is considered as one of the most used methods regarding project prioritization and selection.

This paper is a continuity of a previous work that proposed a theoretical framework that discussed how companies could use information systems to sustain their business models (El Hilali and El Manouar, 2020). Using AHP method will help managers to decide about the right actions to take to reach sustainability.

The article comprises a literature review section in which the concept of sustainability is defined and our framework is introduced. It contains also a methodology section where the AHP method is explained in details. The results of our qualitative study were displayed and discussed next. General conclusions were drawn at the end of the paper.

\section{Research Question}

Decision makers could face many options while implementing actions to sustain their firms' business models. Therefore, the primary goal of our study is to propose to managers a logical technique and steps to follow, in order to choose the right actions to adopt in their quest to reach sustainability.

\section{Literature Review}

\section{- The quest of sustainability}

The concept of sustainability is about finding an equilibrium between three pillars: economic, social and environmental (also known as the three Ps: profit, people and planet) (Beaton and Maser, 2016). Its focus is to 
meet the needs of today without blowing future generations' chances to meet their own needs tomorrow (Spiliakos, 2018).

Sustainability, as a term, was fist launched into the arena of common discourse in 1989 thanks to a United Nation publication known as the "The Brundtland Report". Today, sustainable development has gained widespread business, political and public authority, as well as, it has arguably become "the common currency of almost all players in the environmental arena" (Barkemeyer et al., 2014).

Drivers and motivators to pursue sustainability differ from a company to another. Reputation, brand image, cost savings, innovation, employees' ethics and stakeholders' pressure are the major reasons companies implement sustainability. Table 1 summarizes the reasons for adhering to the sustainability mind-set from two different sources:

Table 1. Summary of Reasons for Implementing Sustainability

\begin{tabular}{cc}
\hline BCG/MIT Survey (Berns et al., 2009) & McKinsey Global Survey (Bonini et al., 2010) \\
\hline Brand image 35\% & Corporate reputation 36\% \\
Cost savings 12\% $\%$ Alignment with business goals $21 \%$ \\
Competitive advantage 10\% & Operational and cost efficiency 19\% \\
Employee morale 9\% & Customers' expectation 19\% \\
Product or service innovation $8.5 \%$ & New growth opportunities $17 \%$ \\
Business model innovation $8 \%$ & Strengthening competitive position $8 \%$ \\
New source of revenue 7.5 $\%$ & Leadership 14 \% \\
Effective risk management 5\% & Regulatory risk 14 \% \\
Enhanced stakeholders' relations 4\% & Motivating employees $11 \%$ \\
Other 1\% & Enhanced stakeholder's relations 5\% \\
& Pressure from NGOs 3\% \\
\hline
\end{tabular}

\section{- Roads to sustainability}

Many articles were published in the literature, in order to discover the ultimate way to reach sustainability. Table 2 summarizes conclusions drawn by the respective authors regarding the most well-known roads to reach sustainability:

Table 2. Main articles discussing ways to reach sustainability

\begin{tabular}{|c|c|c|c|}
\hline Authors & Year & Journal reference & Proposition \\
\hline (Rothenberg, 2007) & 2007 & $\begin{array}{c}\text { MIT Sloan } \\
\text { management review }\end{array}$ & $\begin{array}{l}\text { Sustainability through Servicizing: Shifting from producing } \\
\text { many products to selling services around a fewer range of } \\
\text { products will lead to sustainability. }\end{array}$ \\
\hline $\begin{array}{c}\text { (Nidumolu et al., } \\
\text { 2009) }\end{array}$ & 2009 & $\begin{array}{c}\text { Harvard business } \\
\text { review }\end{array}$ & $\begin{array}{c}\text { Sustainability through innovation: Another way to reach } \\
\text { sustainability is by encouraging innovation through research } \\
\text { and development (R\&D) }\end{array}$ \\
\hline $\begin{array}{c}\text { (Gray and Stites, } \\
\text { 2013) }\end{array}$ & 2013 & $\begin{array}{l}\text { Network for business } \\
\text { sustainability, case } \\
\text { study }\end{array}$ & $\begin{array}{l}\text { Sustainability through partnership: The adopters are } \\
\text { convinced that collaboration is one of the most important } \\
\text { keys to sustain their businesses. They believe that acting } \\
\text { alone will not have as much positive effect as acting } \\
\text { collaboratively. In other words, through partnership, more } \\
\text { value is created than one could alone. }\end{array}$ \\
\hline $\begin{array}{c}\text { (Eccles and } \\
\text { Saltzman, 2011) }\end{array}$ & 2011 & $\begin{array}{c}\text { Stanford Social } \\
\text { Innovation Review }\end{array}$ & $\begin{array}{l}\text { Sustainability through integrated reporting: Integrated } \\
\text { reporting is an emerging concept that actuates companies to } \\
\text { go beyond financial reports by publishing financial and } \\
\text { nonfinancial environmental, social, and governance } \\
\text { performance. }\end{array}$ \\
\hline $\begin{array}{c}\text { (Joyce and Paquin, } \\
\text { 2016) }\end{array}$ & 2016 & $\begin{array}{c}\text { Journal of Cleaner } \\
\text { Production }\end{array}$ & $\begin{array}{l}\text { Sustainability through business models: Adding two layers } \\
\text { (social and environmental) to the business model canvas to } \\
\text { cover the three dimensions of sustainability }\end{array}$ \\
\hline $\begin{array}{c}\text { (Abu-Tayeh and } \\
\text { Myrach, 2016) }\end{array}$ & 2016 & $\begin{array}{l}\text { Workshop of the } \\
\text { International } \\
\text { Conference on } \\
\text { Information Systems }\end{array}$ & $\begin{array}{l}\text { Sustainability Through Information systems (IS): } \\
\text { 3 concepts: } \\
\text { "Sustainability in IS ", a concept that aims to reduce the IS } \\
\text { consumption of resources and its impacts on environment. } \\
\text { "Sustainability by IS" that deals with the contribution of IS } \\
\text { towards a sustainable development } \\
\text { "Sustainability of information system", which concerns the } \\
\text { creation and the modification of IS in a way to optimize } \\
\text { constantly their impacts. }\end{array}$ \\
\hline
\end{tabular}


- Our proposed framework to reach sustainability

In a previous article published in 2020, we proposed a framework that explained how to sustain a business model of a given company through information systems (El Hilali and El Manouar, 2020). We chose the canvas of Osterwalder \& Pigneur's as a basis to work on, in order to reach sustainability given the fact that it is the most used tool (Škerlavaj et al., 2016) to craft a business model.

The idea, as shown in Figure 1, is to regroup the 9 blocks of the business model canvas into 3 categories: blocks related to the economic dimension, those related to society and those related to environment. Sustaining a business model through information systems is assessed by analyzing their impacts on these three categories. Three main questions should be answered:

- How to increase revenues and reduce costs using IS?

- How IS could be used to enhance customer relationships, to segment effectively the customers and to warranty the adhesion of the key partners to sustainability mind-set?

- How IS could play a major role in reducing the environmental impacts of channels and key activities?

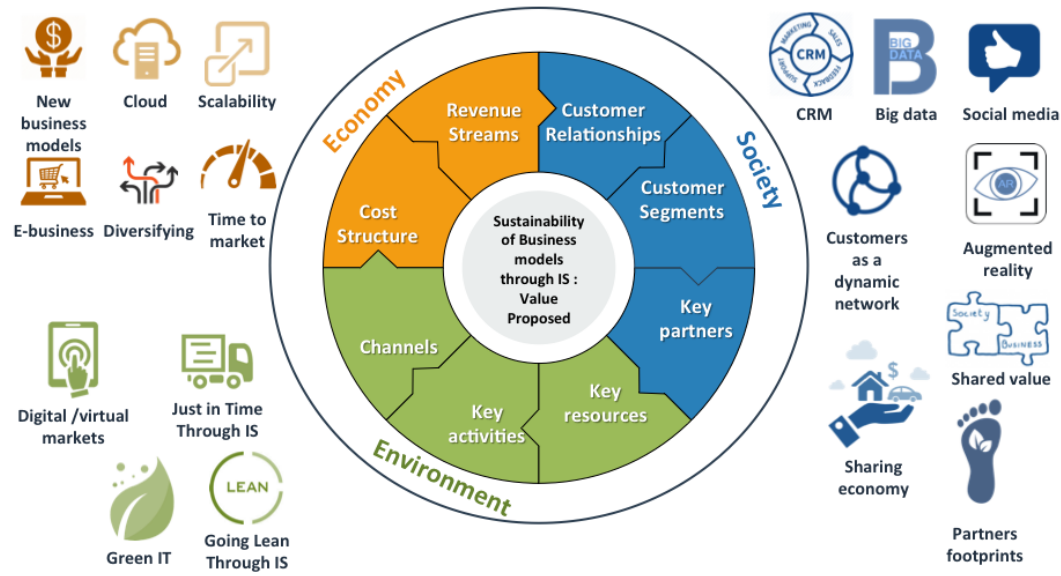

Figure 1. Conceptual framework explaining how to sustain a given business model through IS (El Hilali and El Manouar, 2020)

\section{Methodology}

One of the main challenges that organizations face today resides in their ability to choose the most correct and consistent alternatives in such a way that strategic alignment is maintained. Applying the previous framework (see Figure 1) could put companies in a situation where they are spoiled with choice. Combining the framework with a multicriteria decision making technique, such as the AHP method, will help the decision makers to choose the right actions that depend, in our point of view, on the industry, the firm and the general business climate.

The analytic hierarchy process (AHP) is a structured technique for organizing and analyzing complex decisions based on mathematics. It was first developed by Pr Thomas L. Saaty in the 1070s (Saaty, 1980). This decision making method makes it possible to assign a value representing the preference degree for a given alternative. These values are used to classify alternatives, in order to choose the most suitable solution to a given problem.

Three features have led to AHP's power and popularity as a decision making tool (Jamshidi et al., 2009): (i) its ability to handle both tangible and intangible attributes, (ii) its ability to structure the problems, in a hierarchical manner to gain insights into the decision making process and (iii) its ability to monitoring the consistency with which a decision maker uses his/her judgment.

The strength of this approach is that complex decisions are reduced to a series of one-on-one comparisons. According to (Saaty, 1980), the AHP method could be synthesized in three major phases: decomposition, comparative judgment and synthesis. In the first step, a hierarchy of goal, criteria, sub criteria and alternatives are established to present the problem in a very logical way. Next, the main stakeholders are invited to give their judgements by comparing pairs of criteria or alternatives. In order to express their preferences, evaluators use scale of values ranging from 1 (Equal importance) to 9 (Extreme or absolute importance), as shown in Table 3: 
Table 3. Scale of Relative Importances (according to (Saaty, 1980))

\begin{tabular}{|c|c|}
\hline Scale & Judgment \\
\hline $\mathbf{1}$ & Equal importance \\
\hline $\mathbf{3}$ & Moderate importance of one over the other \\
\hline $\mathbf{5}$ & Essential or strong importance \\
\hline $\mathbf{7}$ & Very strong or demonstrated importance \\
\hline $\mathbf{9}$ & Extreme or absolute importance \\
\hline $\mathbf{2 , 4 , 6 , 8}$ & Intermediate values between the two adjacent judgements \\
\hline
\end{tabular}

Based on preferences derived from the comparison matrix, the last step consists of conducting synthesis of priorities to calculate a composite weight for each alternative.

These three major phases could be more detailed in six steps (Maletič et al., 2016):

Step 1: Define the problem and determine the kind of knowledge sought

Step 2: Structure the complex decision problem as a hierarchy of goal, criteria and alternatives

Step 3: Construct a set of pairwise comparison matrices. Formally, the pairwise comparisons are collected into a pairwise comparison matrix, $A=\left(a_{i j}\right) n \times n$, structured as follows:

$$
\left(\begin{array}{ccc}
\mathrm{a} 11 & \cdots & \mathrm{a} 1 \mathrm{n} \\
\vdots & \ddots & \vdots \\
\mathrm{an} 1 & \cdots & \mathrm{ann}
\end{array}\right)
$$

with $a_{i j}>0$ expressing the degree of preference of $x_{i}$ to $x_{j}$.

Step 4: Extract the relative importance implied by the previous comparisons to answer how important are the alternatives when they are considered in terms of the criterion? Saaty (Saaty, 1980) asserts that to do this, we should estimate the right principal eigenvector of the previous matrix. Given a judgment matrix with pairwise comparisons, the corresponding maximum left eigenvector is approximated by using the geometric mean of each row. That is, the elements in each row are multiplied with each other and then the $n$-the root is taken (where $n$ is the number of elements in the row) (Triantaphyllou and Mann, 1995). The numbers are next normalized by dividing them with their sum.

Step 5: Verify the consistency of the comparisons. The Pairwise comparison matrix will be consistent if the following relation is true: $a_{i j}=a_{i k} a_{k j}$. However, perfect consistency rarely occurs in practice. The AHP method uses the consistency ratio CR to check the consistency of the pairwise comparisons in a judgment matrix, which should be less than $10 \%$ (Triantaphyllou and Mann, 1995). To compute CR, the consistency index (CI) should be estimated. First, we multiplying the sum of the column of the pairwise matrix with the normalized eigenvector to compute the maximum eigenvalue $\lambda_{\max }$. CI is calculated by using the formula: $\mathrm{CI}=\left(\lambda_{\max }-n\right) /(n-1)$.

CR is computed by dividing CI with the Random Consistency index (RCI) given in the following Table 4 (values depending on n) (JEDDOU et al., 2015):

Table 4. RCI values for different values of $n$

\begin{tabular}{|c|c|c|c|c|c|c|c|c|c|}
\hline $\mathbf{n}$ & 1 & 2 & 3 & 4 & 5 & 6 & 7 & 8 & 9 \\
\hline $\mathbf{R C I}$ & 0 & 0 & 0.58 & 0.9 & 1.12 & 1.24 & 1.32 & 1.41 & 1.45 \\
\hline
\end{tabular}

Below, Table 5 that sum up the step 5: 
Table 5. Calculations to Obtain the Vector Criteria

\begin{tabular}{|c|c|c|c|c|c|c|}
\hline Criteria & C1 & $\mathrm{C} 2$ & $\mathbf{C 3}$ & Cn & Eigenvector & Criteria vector \\
\hline C1 & 1 & $a_{12}$ & $a_{13}$ & $a_{1 n}$ & \multirow{4}{*}{$\mathrm{V}_{\mathrm{j}}=\prod_{i=1}^{n} a i j^{\wedge}\left({ }^{1} / n\right)$} & $\mathrm{W}_{\mathrm{j}}=\mathrm{V}_{\mathrm{j}} / \sum \mathrm{V}_{\mathrm{j}}$ \\
\hline C2 & $1 / \mathrm{a}_{12}$ & 1 & $a_{23}$ & $a_{2 n}$ & & $\mathrm{~W}_{\mathrm{j}}=\mathrm{V}_{\mathrm{j}} / \sum \mathrm{V}_{\mathrm{j}}$ \\
\hline $\mathrm{C3}$ & $1 / a_{13}$ & $1 / \mathrm{a}_{23}$ & 1 & $a_{3 n}$ & & $\mathrm{~W}_{\mathrm{j}}=\mathrm{V}_{\mathrm{j}} / \sum \mathrm{V}_{\mathrm{j}}$ \\
\hline Cn & $1 / \mathrm{a}_{1 \mathrm{n}}$ & $1 / \mathrm{a}_{2 \mathrm{n}}$ & $1 / a_{3 n}$ & 1 & & $\mathrm{~W}_{\mathrm{j}}=\mathrm{V}_{\mathrm{j}} / \sum \mathrm{V}_{\mathrm{j}}$ \\
\hline Eigenvalue $\lambda_{\max }$ & \multicolumn{4}{|c|}{$\left(\sum_{i=1}^{n} a i j\right) * \mathrm{Wj}$} & $\sum V j$ & $\sum w j=1$ \\
\hline $\begin{array}{l}\text { Consistency } \\
\text { Ration (CR) }\end{array}$ & \multicolumn{6}{|c|}{$\frac{(\lambda \max -n) /(n-1)}{R I}$} \\
\hline
\end{tabular}

Step 6: The synthesis step is taken. The priority vectors become the columns of the decision matrix. In order to obtain final results, all alternatives were multiplied by the global weight of the single decision criteria.

Furthermore, in order to explain well how could we associate the AHP method with the framework detailed in Figure 1, we chose to work on a telecom operator as a case study. The chosen company is the historical operator in Morocco, with more than 8000 employees and \$ 3.4 billion as revenue of 2018.

Case studies have in fact the merit of enabling theory building and development more than quantitative research approaches in the field of management (Tsang, 2014). Moreover, they are capable to explain complex connections between phenomena and their context (Dubois and Gadde, 2002). Furthermore, case studies offer the possibility of collecting and analyzing different form of data, allowing a more in depth understanding of the analyzed subject (McCutcheon and Meredith, 1993).

\section{Results}

Following the 6 steps detailed in Methodology section, our finding for the telecom operator could be presented as follow:

Step 1: The objective of this study is to choose the best alternative for a telecom operator to embrace sustainability. Investing in sustainability requires implementing radical changes at the business model level. In the digital era, these actions could not be done without having recourse to digital capabilities and information systems (El Hilali et al., 2020). Therefore, the objective is to sustain the business model of the Telco through information systems by working on the business models canvas elements.

Step 2: The objective of this study was decomposed in three criteria, which are economic development, social growth and environmental performance. 8 sub-criteria where identified from our framework as to form a hierarchical abstraction of the problem, as shown in the following Figure 2 


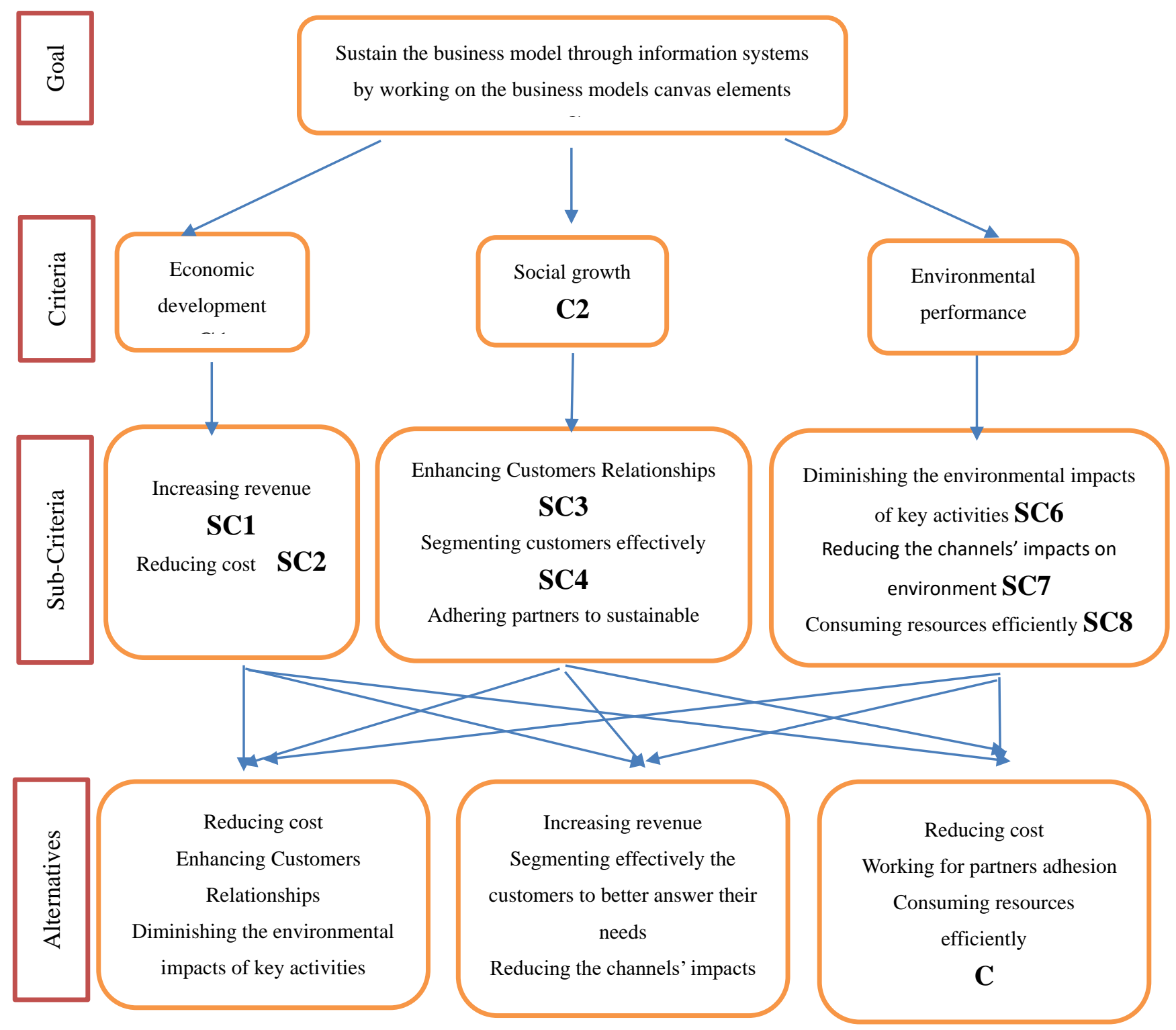

Figure 2. Criteria, sub-criteria and alternatives of the AHP method for the telecom operator

Steps 3,4 and 5: In this step, 10 managers with IT and managerial background that work in the telecom operator in Morocco were consulted, in order to collect their judgments. Pairwise comparison matrices were established as follow:

\section{- Criteria}

Table 6. The pairwise comparison matrix for the three criteria

\begin{tabular}{|c|c|c|c|c|c|}
\hline & Economy & Society & Environment & Eigenvector & Normalized EV \\
\hline Economy & 1 & 3 & 2 & 1.82 & 0.54 \\
\hline Society & 0.33 & 1 & 0.5 & 0.55 & 0.16 \\
\hline Environment & 0.5 & 2 & 1 & 1 & 0.30 \\
\hline
\end{tabular}




\section{Lambda max CI CR

$\begin{array}{lll}3.009 & 0.0046 & 0.008\end{array}$

\section{- Sub criteria}

Table 7. The pairwise comparison matrix for the first sub-criteria

\begin{tabular}{|c|c|c|c|c|}
\hline & Increasing Revenue & reducing cost & EV & Normalized EV \\
\hline Increasing Revenue & 1 & 2 & 1.41 & 0.667 \\
\hline reducing cost & 0.50 & 1 & 0.71 & 0.333 \\
\hline
\end{tabular}

$\begin{array}{ccc}\text { Lambda max } & \text { CI } & \text { CR } \\ 2.000 & 0.0000 & 0.000\end{array}$

Table 8 . The pairwise comparison matrix for the second sub-criteria

\begin{tabular}{|c|c|c|c|c|c|}
\hline & $\begin{array}{c}\text { Enhancing } \\
\text { Customers } \\
\text { Relationships }\end{array}$ & $\begin{array}{c}\text { Segmenting } \\
\text { customers } \\
\text { effectively }\end{array}$ & $\begin{array}{c}\text { Adhering partners } \\
\text { to sustainable } \\
\text { mindset }\end{array}$ & EV & $\begin{array}{c}\text { Normalized } \\
\text { EV }\end{array}$ \\
\hline $\begin{array}{c}\text { Enhancing } \\
\text { Customers } \\
\text { Relationships }\end{array}$ & 1 & & & & \\
\hline $\begin{array}{c}\text { Segmenting } \\
\text { customers } \\
\text { effectively }\end{array}$ & 0.17 & 6 & 4 & 8.8 & 0.701 \\
\hline $\begin{array}{c}\text { Adhering partners to } \\
\text { sustainable mindset }\end{array}$ & 0.25 & 1 & & & \\
\hline
\end{tabular}

$\begin{array}{ccc}\text { Lambda max } & \text { CI } & \text { CR } \\ 3.009 & 0.0046 & 0.008\end{array}$

Table 9. The pairwise comparison matrix for the third sub-criteria

\begin{tabular}{|c|c|c|c|c|c|}
\hline & $\begin{array}{c}\text { Diminishing the } \\
\text { environmental impacts of } \\
\text { key activities }\end{array}$ & $\begin{array}{c}\text { Reducing the channels' } \\
\text { impacts on } \\
\text { environment }\end{array}$ & $\begin{array}{c}\text { Consuming } \\
\text { resources } \\
\text { efficiently }\end{array}$ & $\begin{array}{c}\text { E } \\
\text { V }\end{array}$ & $\begin{array}{c}\text { Normal } \\
\text { ized } \\
\text { EV }\end{array}$ \\
\hline $\begin{array}{c}\text { Diminishing the } \\
\text { environmental impacts of } \\
\text { key activities }\end{array}$ & 1 & 2 & 2 & 1. & 5 \\
\hline $\begin{array}{c}\text { Reducing the channels' } \\
\text { impacts on environment }\end{array}$ & 0.50 & 1 & 0.5 & 0.493 \\
\hline $\begin{array}{c}\text { Consuming resources } \\
\text { efficiently }\end{array}$ & 0.50 & 2 & 1 & 0.196 \\
\hline
\end{tabular}


Lambda max 3.054
CI

0.0268
CR

0.046

Step 6: final priorities will be computed as follow:

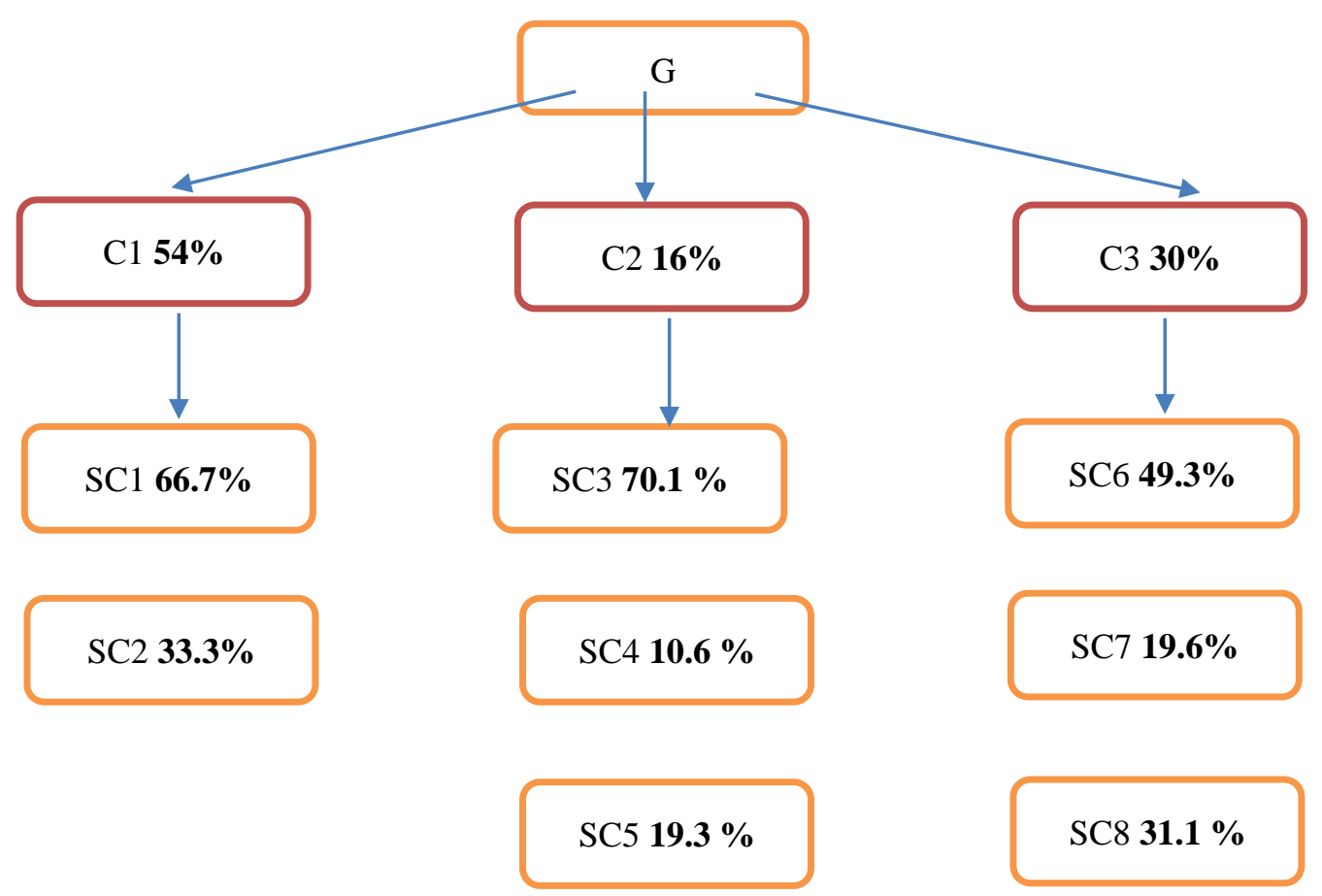

Figure 3. The computed final priorities

For alternative A, the final weight will be: $54 \% * 33.3 \%+16 \% * 70.1 \%+30 \% * 49.3 \%=44 \%$

For alternative B, the weight is computed as: $54 \% * 66.7 \%+16 \% * 10.6 \%+30 \% * 19.6 \%=43.6 \%$

And finally, the alternative $\mathrm{C}$ will have as a weight: $54 \% * 33.3 \%+16 \% * 19.3 \%+30 \% * 31.1 \%=30.4 \%$

\section{Discussion}

Sustainability is almost the quest of every company nowadays. Finding an equilibrium between the economic ambitious, the social and environmental footprints is what companies are looking for.

Deciding on which actions to take could be very difficult in case of unanimous decisions. Offering logical decision making steps and tools to help to choose the best option will be welcome. Actions will depend on industries, companies and their ways of creating value. Working on business models, in this case, may help decision makers in their quest of sustaining their business.

Our framework is based on the AHP method, a well-known multicriteria decision making technique that helps decision makers to select a choice between alternatives. The framework was applied on a telecom operator as a case study, in order to explain it in clear way.

For the Telco, three scenarios were kept by the questioned managers in order to increase the firm's sustainability footprints. Scenario A is primally based on reducing costs, enhancing customers relationships and diminishing the environmental impacts of key activities. Scenario B proposes to the Telco to increase revenue, segment effectively the customers to better answer their needs and to reduce the channels impacts on the environment. The proposed scenario $\mathrm{C}$ takes account reducing costs, working on the adhesion of the partners and consuming resources effectively.

Scenarios A and B were by far the preferred choices to the company. Choosing between reducing costs and increasing revenue is a recurring question for business owners. Experts and practitioners believe that deciding on 
cutting costs or increasing revenue often depends on the company and the industry in which it operates (Maverick, 2020). Any decision should increase profitability and especially the profit margin that measures how much, out of every dollar in sales, a company actually keeps in earnings. In some cases, increasing revenue can result in higher costs and lower profit margins, while cutting costs can result in diminished sales and also lower profit margins if market share is lost over time. Companies should focus on branding and quality, in order to sustain higher prices on sales and ensure higher profit margins.

Regarding the social part, both the scenarios A and B privileged customer centricity. In fact, Firms these days are putting customers at the heart of their organization (Fader and Toms, 2018). They are privileging providing a positive customer experience before and after sales, in order to enhance customer loyalty and to improve business growth (Giménez, 2018). Moreover, our telecom operator is following the trend by thinking customer first. In the highly competitive telecom industry, customer service and customer experience are critical factors in building and maintaining a competitive advantage (McShane and America, 2012). In addition, the telecom operator decided to not be left out. On the one hand, enhancing the customer relationships through customization, personalization, focusing less on the sales and adopting new mindsets, such as shared value and circular economy, will enhance the social foot print of the telecom operator. On the other hand, segmenting effectively the customers will help the Telco to better understand what customers want and what they do not want, in order to address their social needs. As regards to the environmental actions, scenario A suggests to prioritize diminishing the impacts of the Telco key activities. Free cooling technics, digital marketing, adopting lean/just in time approaches to manage inventories. These are few of many actions that can be adopted by the operator to reduce its carbon footprint. Scenario B, however, proposes to reduce the impacts of the channels. In fact, with selfcare solutions through websites, mobile applications and customer service ChatBots deployed on the main social networks used in Morocco (Facebook messenger and WhatsApp), the operator could reduce significantly its channels impacts on the environment as it will minimize the necessity of a customer to visit a brick and mortar salespoint.

\section{Conclusion}

This paper was an attempt to enrich the literature on the subject of sustainability and multicriteria decision making techniques. It introduced a new approach, based on our already published framework and the AHP method that offers to decision makers a logical technique to choose and implement the best options regarding their quest for sustainability. This approach was applied on a telecom operator as a case study, in order to explain it well.

As future research directions, we could explore the use of other multicriteria decision making techniques and other sustainability frameworks, in order to give firms more flexibility and options while searching for the ultimate way to reach sustainability.

\section{References}

Abu-tayeh, G., \& Myrach, T. (2016). Properties of Sustainable Information Systems.

Barkemeyer, R., Holt, D., Preuss, L., \& Tsang, S. (2014). What happened to the 'development'in sustainable development? Business guidelines two decades after Brundtland. Sustainable development, 22, 15-32. https://doi.org/10.1002/sd.521

Beaton, C. R. \& Maser, C. (2016). Economics and Ecology: United for a Sustainable World. CRC Press. https://doi.org/10.1201/b11060

Berns, M., Townend, A., Khayat, Z., Balagopal, B., Reeves, M., Hopkins, H. S., \& kruschwitz, N. (2009). The Business of Sustainability: What It Means to Managers Now.

Bonini, S., Görner, S., \& Alissa, J. (2010). How companies manage sustainability: McKinsey Global Survey results [Online]. Retrieved May 23, 2018, from https://www.mckinsey.com/business-functions/sustainability-and-resource-productivity/our-insights/how-co mpanies-manage-sustainability-mckinsey-global-survey-results

Dubois, A., \& Gadde, L. E. (2002). Systematic combining: an abductive approach to case research. Journal of Business Research, 55, 553-560. https://doi.org/10.1016/S0148-2963(00)00195-8

Eccles, R. G., \& Saltzman, D. (2011). Achieving sustainability through integrated reporting. Stanford Social Innovation Review, 9, 56-61.

El Hilali, W., \& El Manouar, A. (2020). Sustainability through information systems: how can information systems lead to sustainable business models? International Journal of Business Information Systems, 33, 
225-249. https://doi.org/10.1504/IJBIS.2020.10026831

EL Hilali, W., El Manouar, A., \& Idrissi, M. A. J. (2020). Reaching sustainability during a digital transformation: a PLS approach. International Journal of Innovation Science. https://doi.org/10.1108/IJIS-08-2019-0083

Fader, P. S., \& Toms, S. E. (2018). The Customer Centricity Playbook: Implement a Winning Strategy Driven by Customer Lifetime Value. Wharton School Press.

Giménez, J. F. V. (2018). Customer-Centricity: The New Path to Product Innovation and Profitability, Cambridge Scholars Publishing.

Gray, B., \& Stites, J. P. (2013). Sustainability through partnerships. Capitalizing on collaboration. Network for business sustainability, case study, 24, 1-110.

Jamshidi, J., Ataei, M., Sereshki, F., \& Seyed, M. J. (2009). The application of AHP approach to selection of optimum underground mining method, case study: Jajarm Bauxite Mine (Iran). Archives of Mining Sciences, 54, 103-117.

Jeddou, M. B., Kalboussi, W. B., \& Dhouibi, A. (2015). Application de la méthode AHP pour le choix multicritères des fournisseurs. Revue Marocaine de recherche en management et marketing.

Joyce, A., \& Paquin, R. L. (2016). The triple layered business model canvas: A tool to design more sustainable business models. Journal of cleaner production, 135, 1474-1486. https://doi.org/10.1016/j.jclepro.2016.06.067

Maletič, D., Lasrado, F., Maletič, M., \& Gomišček, B. (2016). Analytic hierarchy process application in different organisational settings. Applications and Theory of Analytic Hierarchy Process: Decision Making for Strategic Decisions, 89. https://doi.org/10.5772/64511

Maverick, J. B. (2020). Is it more important for a company to lower costs or increase revenue? [Online]. Retrieved May 27, 2020, from https://www.investopedia.com/ask/answers/122214/company-it-more-important-lower-costs-or-increase-rev enue.asp

Mccutcheon, D. M., \& Meredith, J. R. (1993). Conducting case study research in operations management. Journal of Operations Management, 11, 239-256. https://doi.org/10.1016/0272-6963(93)90002-7

Mcshane, K., \& America, N. (2012). Customer Centricity in the Telecommunications Industry. Pitney Bowes Software.

Nidumolu, R., Prahalad, C. K., \& Rangaswami, M. R. (2009). Why sustainability is now the key driver of innovation. Harvard business review, 87, 56-64.

Rothenberg, S. (2007). Sustainability through servicizing. MIT Sloan management review, 48, 83.

Saaty, T. L. (1980). The Analytic Hierarchy Process: Planning, Priority Setting, Resource Allocation, McGraw-Hill.

Škerlavaj, M., Černe, M., Dysvik, A., \& Carlsen, A. (2016). Capitalizing on Creativity at Work: Fostering the Implementation of Creative Ideas in Organizations. Edward Elgar Publishing, Incorporated. https://doi.org/10.4337/9781783476503

Spiliakos, A. (2018). What Does "Sustainability" Mean in Business? [Online]. Harvard business school online. Retrieved June 14, 2020, from Available: https://online.hbs.edu/blog/post/what-is-sustainability-in-business

Triantaphyllou, E., \& Mann, S. H. (1995). Using the analytic hierarchy process for decision making in engineering applications: some challenges. International Journal of Industrial Engineering: Applications and Practice, 2, 35-44.

Tsang, E. W. K. (2014). Generalizing from Research Findings: The Merits of Case Studies. International Journal of Management Reviews, 16, 369-383. https://doi.org/10.1111/ijmr.12024

\section{Copyrights}

Copyright for this article is retained by the author(s), with first publication rights granted to the journal.

This is an open-access article distributed under the terms and conditions of the Creative Commons Attribution license (http://creativecommons.org/licenses/by/4.0/). 